\title{
Influence of natural radium contamination of barium chloride on the determination of radium isotopes in the water samples using $\alpha / \beta$ liquid scintillation spectrometry
}

Chau Nguyen Dinh, Magdalena Czechowska, Jakub Nowak, Pawel Jodłowski

\begin{abstract}
The determination of radium isotopes in drinking water by liquid scintillation technique requires some reagents that are used for separating radium from water samples. One of the main reagents is $\mathrm{BaCl}_{2} \cdot \mathrm{H}_{2} \mathrm{O}$. This paper presents the study of this compound and shows that barium chloride reagent is naturally contaminated with ${ }^{226} \mathrm{Ra}$. The ${ }^{226} \mathrm{Ra}$ activity concentration in $\mathrm{BaCl}_{2} \cdot \mathrm{H}_{2} \mathrm{O}$ reagent produced by chemical companies from Poland and other countries is equal to a few dozen $\mathrm{Bq} / \mathrm{kg}$. Furthermore, $14 \mathrm{~mL}$ of $0.10 \mathrm{M} \mathrm{BaCl}_{2} \cdot \mathrm{H}_{2} \mathrm{O}$ solution is the optimum amount which should be used for the chemical procedure. At the optimum amount of barium chloride and 2-hour measurement, the detection limit of ${ }^{226} \mathrm{Ra}$ and ${ }^{228} \mathrm{Ra}$ of the liquid scintillation counting method is equal to 5 and $30 \mathrm{mBq}$ per sample, respectively.
\end{abstract}

Key words: $\alpha / \beta$ liquid scintillation spectrometry $\bullet$ barium chloride $\bullet$ radium isotopes $\bullet$ detection limit

C. N. Dinh, M. Czechowska, J. Nowak ${ }^{凶}$, P. Jodłowski AGH University of Science and Technology, 30 Mickiewicza Ave., 30-059 Kraków, Poland, Tel.: +48 12617 3778,

E-mail: jakub.nowak@fis.agh.edu.pl

Received: 13 May 2016

Accepted: 4 August 2016

\section{Introduction}

There are four natural radium isotopes found in the environment: ${ }^{226} \mathrm{Ra}$ (belongs to uranium-radium series) with decay period $T_{1 / 2}=1620 \mathrm{y},{ }^{228} \mathrm{Ra}$ and ${ }^{224} \mathrm{Ra}$ (both isotopes belong to thorium series) with $T_{1 / 2}=5.75 \mathrm{y}$ and $T_{1 / 2}=3.64 \mathrm{~d}$, respectively, and ${ }^{223} \mathrm{Ra}$ with $T_{1 / 2}=11.2 \mathrm{~d}$, the member of uranium-actinium series. The isotopes are ubiquitous in all environmental spheres (lithosphere, hydrosphere, atmosphere, and biosphere). Radium isotopes can easily migrate from one environmental system to the other and from soil into vegetables [1]. In hydrosphere, the heavy metals and radium isotopes often accumulate in fishes and mussels, which are then soaked in human and animal bodies as food [2-8]. The industrial boilers used for a long time can be contaminated by a significant amount of radium isotopes [9]. The harmfulness of radium isotopes to human health has been known since the twenties of the last century, when women painters suffered from bone sarcomas resulting from the fluorescence powder containing significant amount of radium used to make watch faces [10]. The probability of bone cancer resulting from the daily consumption of two liters water containing only $18.5 \mathrm{mBq} / \mathrm{L}$ of ${ }^{226} \mathrm{Ra}$ through 70 years amounts to $4 \times 10^{-5}[11]$. The contribution of radium isotopes to the annual committed effective dose resulting from drinking water consumption is around 50\% [12-18]. According to 
the WHO recommendations, the annual committed effective dose resulting from the intake of natural radionuclides in drinking water and food materials should be lower than $0.1 \mathrm{mSv}$ [19]. Following the Council Directive 2013/51/EURATOM [20], the detection limit (DL) of routine methods for radium isotopes measurements in water intended for human consumption should be equal to $40 \mathrm{mBq} / \mathrm{L}$ for ${ }^{226} \mathrm{Ra}$ and $80 \mathrm{mBq} / \mathrm{L}$ for ${ }^{228} \mathrm{Ra}$. Moreover, the DL of specific methods for controlling purposes should reach $20 \mathrm{mBq} / \mathrm{L}$ for ${ }^{228} \mathrm{Ra}$ and $40 \mathrm{mBq} / \mathrm{L}$ for ${ }^{226} \mathrm{Ra}$. The radium isotopes concentrations in aquatic samples are often determined using liquid scintillation counting (LSC) method or gamma spectrometry $[1,5,12,14$, 17]. Water sample volume for radium determination by LSC method ranges from $2-5 \mathrm{~L}$, but the DL of LSC method for ${ }^{228} \mathrm{Ra}$ is equal to $30 \mathrm{mBq} / \mathrm{L}[14,15$, 17]. It is worth adding that the expected annual committed effective dose for teenagers (12-17 years old) and infants (below 1 year) resulting from the consumption of water containing ${ }^{228}$ Ra near $30 \mathrm{mBq} / \mathrm{L}$ is higher than the permissible level $(0.1 \mathrm{mSv})$. In order to apply the LSC technique as a routine method for determination of radium isotopes in water samples and to meet the requirements in accordance with the Council Directive 2013/51/EURATOM [20], this work focused on: (i) the influence of barium chloride $\left(\mathrm{BaCl}_{2} \cdot \mathrm{H}_{2} \mathrm{O}\right)$ on alpha and beta background levels; (ii) the optimization of $\mathrm{BaCl}_{2} \cdot \mathrm{H}_{2} \mathrm{O}$ amount to be used for the radium co-precipitation from water sample; (iii) experimental determination of DL of ${ }^{226} \mathrm{Ra}$ and ${ }^{228} \mathrm{Ra}$ with optimum amount of $\mathrm{BaCl}_{2} \cdot \mathrm{H}_{2} \mathrm{O}$.

\section{Measurements}

\section{Barium chloride}

$\mathrm{BaCl}_{2} \cdot \mathrm{H}_{2} \mathrm{O}$ is one of the principal reagents used for separation of radium isotopes from the aqueous samples. $\mathrm{BaCl}_{2} \cdot \mathrm{H}_{2} \mathrm{O}$ pure for analysis (cz.d.a. - Polish abbreviation), provided by POCH S.A., was used for chemical separation. In order to investigate the influence of this reagent on the alpha and beta count rates from the background sample, six samples were prepared from the deionized water and numbered from 1 to 6 . The amounts $8,10,12,14,16$, and $18 \mathrm{~mL}$ of the solution of $0.10 \mathrm{M} \mathrm{BaCl} \cdot \mathrm{H}_{2} \mathrm{O}$ were added to the samples $1,2,3,4,5$, and 6 , respectively. Next, the obtained precipitates were purified by dissolving them in ethylenediaminetetraacetic acid (EDTA) $0.25 \mathrm{M}$, and then, radium was again precipitated following the procedures described by several analysts $[14,17,18,21]$. The time of the last precipitation for each sample was recorded. The precipitate was placed in a $22-\mathrm{mL}$ glass vial and then, $4 \mathrm{~mL}$ deionized water and $12 \mathrm{~mL}$ gel scintillation cocktail were added to the precipitate and they were mixed together. The samples were measured using 1414 Guardian Wallac $\alpha / \beta$ Liquid Scintillation Counter ${ }^{\top \mathrm{M}}$. Each sample was measured for $2 \mathrm{~h}$, and this was repeated every day until the expected equilibrium between ${ }^{226} \mathrm{Ra}$ and its short lived progeny ${ }^{222} \mathrm{Rn}$ was established (above 20 days).

\section{Results and discussion}

Figures $1 \mathrm{a}$ and $1 \mathrm{~b}$ show the count rates in alpha and beta channels measured for the background samples prepared from distilled water with different amounts of $\mathrm{BaCl}_{2} \cdot \mathrm{H}_{2} \mathrm{O}$, as functions of the time elapsed after precipitation (for clarity of figures, the error bars were only displayed for selected measurement points).

In these figures, the count rates measured in alpha and beta channels for blank sample were also presented. The blank sample is defined as a sample consisting of $6 \mathrm{~mL}$ deionized water mixed with $12 \mathrm{~mL}$ gel scintillation cocktail. The measured count rates for the blank sample were regarded as a background radiation (originating from the cosmic rays, surrounding materials, electronic circuits, glass vial and scintillation cocktail) excluding the chemical reagents. Figures $1 \mathrm{a}$ and $1 \mathrm{~b}$ show that: (a) the measured count rates in alpha and beta channels for the blank sample ranged from 1 to $3 \mathrm{cpm}$ and from 19 to $22 \mathrm{cpm}$, respectively; (b) the count rates for all prepared background samples increased exponentially as time elapsed and reached a plateau after approximately $500 \mathrm{~h}$; (c) the count rate increased with the amount of barium chloride solution used in the chemical procedure. The mentioned phenomena showed an evidence of contamination of the barium chloride reagent by radium isotopes. Based on the measured count rates for prepared samples, the activity concentration of ${ }^{22} \mathrm{Ra}$ in $\mathrm{BaCl}_{2} \cdot \mathrm{H}_{2} \mathrm{O}$ powder was determined, which was equal to 62 (6) $\mathrm{Bq} / \mathrm{kg}$, and no ${ }^{228} \mathrm{Ra}$. The ${ }^{226} \mathrm{Ra}$ concentration in the $\mathrm{BaCl}_{2} \cdot \mathrm{H}_{2} \mathrm{O}$ powder was also determined by the gamma
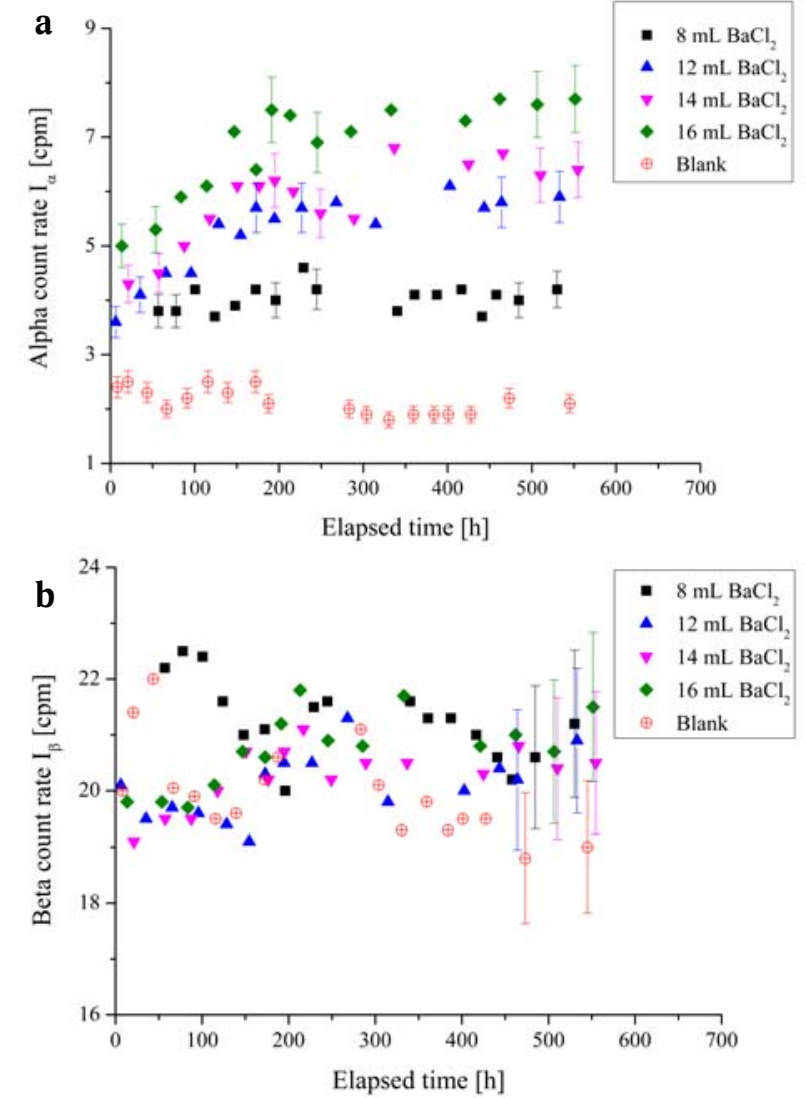

Fig. 1. Results of measured alpha (a) and beta (b) count rates as a function of the time elapsed from the precipitation moment for background samples. 


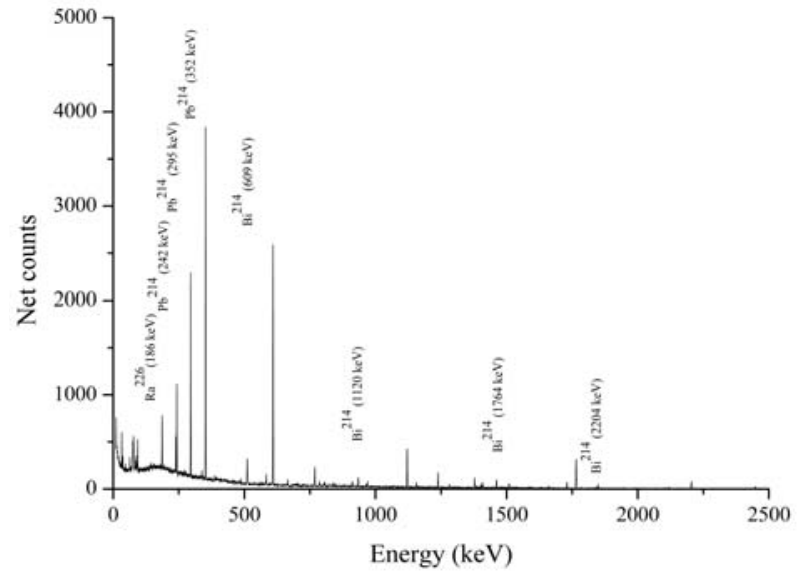

Fig. 2. Gamma spectrum of the $\mathrm{BaCl}_{2} \cdot \mathrm{H}_{2} \mathrm{O}$ powder. spectrometer coupled with high-purity germanium detector. Figure 2 presents the measured spectrum of gamma rays emitted from $\mathrm{BaCl}_{2} \cdot \mathrm{H}_{2} \mathrm{O}$ powder sample, tightly packed in the aluminium beaker at the time of experiment, guaranteeing the establishment of the radioactive equilibrium between ${ }^{226} \mathrm{Ra}$ and its progeny. The spectrum (Fig. 2) composes of only the peaks of gamma rays from ${ }^{226} \mathrm{Ra}$ and it progeny, and does not show any peaks from other isotopes. Based on the area of peaks $186 \mathrm{keV}$ from ${ }^{226} \mathrm{Ra}, 609 \mathrm{keV}$ and $1760 \mathrm{keV}$ both from ${ }^{214} \mathrm{Bi}$, the ${ }^{226} \mathrm{Ra}$ content was assessed following the method described by Jodłowski and Kalita [12], and it amounted to 56 (3) Bq/ $/ \mathrm{kg}$. The contamination of barium chloride with ${ }^{226} \mathrm{Ra}$ was also noted by Saito et al. [22] and they reported that ${ }^{226} \mathrm{Ra}$ content in Japanese $\mathrm{BaCl}_{2} \cdot \mathrm{H}_{2} \mathrm{O}$ powder ranged from 20 to $100 \mathrm{~Bq} / \mathrm{kg}$.

As a consequence of ${ }^{226} \mathrm{Ra}$ contamination, the more of barium chloride is used in precipitation procedure the more contribution of ${ }^{226} \mathrm{Ra}$ from this reagent to the count rates. On the other hand, lower the amount of this reagent, lower is the chemical recovery in the chemical procedure. Therefore, the optimum amount of barium chloride used in the chemical procedure should be determined. The optimum amount was defined as the amount for which the chemical recovery should be higher than $95 \%$ and the background level should be as low as possible.

In order to determine the optimum amount of barium chloride, six pairs of samples were prepared. Each pair consisted of one sample prepared from the ${ }^{226} \mathrm{Ra}$ standard solution (standard sample) and the other prepared from the deionized water (background sample). The ${ }^{226} \mathrm{Ra}$ activity concentrations of all the standard samples were same and equal to 1.0 Bq. During the chemical procedure, both samples of the given pair were spiked with same amount of $\mathrm{BaCl}_{2} \cdot \mathrm{H}_{2} \mathrm{O}$ $0.10 \mathrm{M}$ solution. The amounts of $\mathrm{BaCl}_{2} \cdot \mathrm{H}_{2} \mathrm{O}$ $0.10 \mathrm{M}$ solution used for pairs $1-6$ were $6,8,10,12$, and $14 \mathrm{~mL}$, respectively. The samples were prepared following the same procedure mentioned in the measurement paragraph. The net count rates measured in alpha and beta channels of six standard samples vs. the elapsed time are presented in Figs. 3a and $3 \mathrm{~b}$ (for clarity of figures, the error bars were only displayed for selected measurement points).

The net count rate of a given standard sample was obtained by subtracting the count rate of the
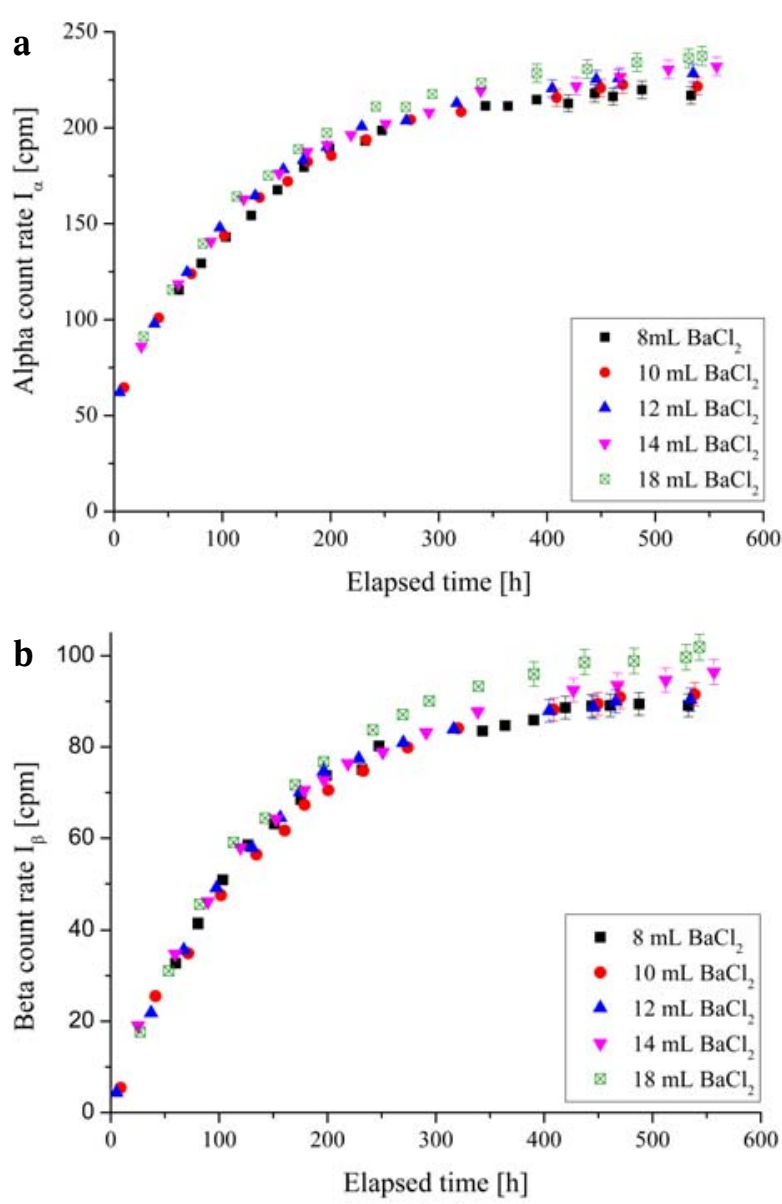

Fig. 3. Results of measured alpha (a) and beta (b) count rates as a function of the time elapsed from the precipitation moment for standard samples.

background from the count rate of the sample in the given pair. The measured count rate increased with the amount of $\mathrm{BaCl}_{2} \cdot \mathrm{H}_{2} \mathrm{O}$ (Fig. 3a). The chemical recovery is defined as the ratio of determined ${ }^{226} \mathrm{Ra}$ activity to its total content in the water sample. Based on the relationship between the obtained chemical efficiencies and the amount of solution of $0.10 \mathrm{M} \mathrm{BaCl} \cdot \mathrm{H}_{2} \mathrm{O}$ used in sample preparation, $14 \mathrm{~mL}$ of this solution was chosen as an optimum volume for the radium co-precipitation procedure (Fig. 4).

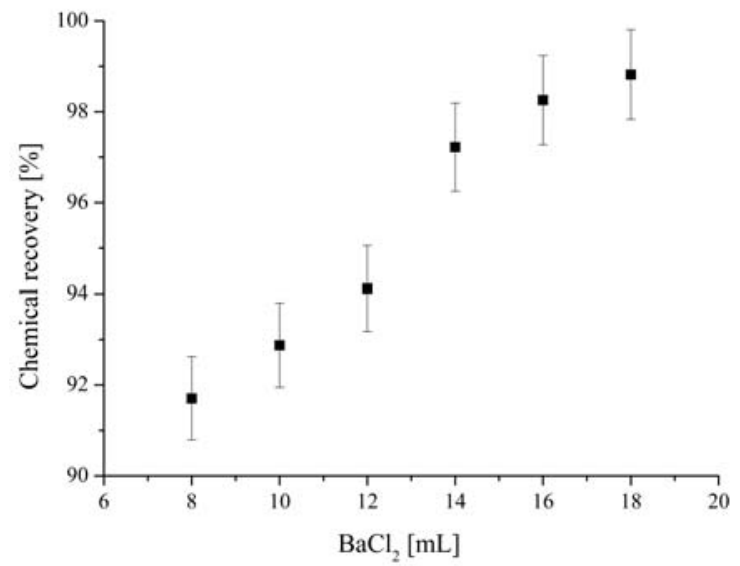

Fig. 4. The chemical recovery as a function of amount of solution of $0.10 \mathrm{M} \mathrm{BaCl}_{2} \cdot \mathrm{H}_{2} \mathrm{O}$ used in the sample preparation. 


\section{Detection limit}

The DL is the lowest quantity of a radioactive substance distinguished from the absence of that substance (a blank value) within a stated confidence interval, which is generally equal to $95 \%$ [23]. The DL can be estimated by the formula:

$$
\mathrm{DL}=3.29 \cdot \sigma_{\mathrm{B}}
$$

where $\sigma_{\mathrm{B}}$ is uncertainty of the background sample.

The uncertainty of the background sample prepared using $14 \mathrm{~mL}$ of $0.10 \mathrm{M} \mathrm{BaCl}_{2} \cdot \mathrm{H}_{2} \mathrm{O}$ aqueous solution measured for two hours using the 1414 Guardian Wallac scintillation spectrometer is equal to 0.4 and $1.2 \mathrm{cpm}$ for alpha and beta count rates, respectively. It means that the content of ${ }^{226} \mathrm{Ra}$ or ${ }^{228} \mathrm{Ra}$ in the investigated water sample can be determined by the LSC method when net alpha or beta count rate is higher than $1.3 \mathrm{cpm}$ or $3.95 \mathrm{cpm}$, respectively, and the DL is equal to $0.005 \mathrm{~Bq}$ for ${ }^{226} \mathrm{Ra}$ and $0.030 \mathrm{~Bq}$ for ${ }^{228} \mathrm{Ra}$.

\section{Conclusions}

Barium chloride is the principal reagent used in the precipitation of radium isotopes from the aqueous sample as a form of $(\mathrm{Ra}, \mathrm{Ba}) \mathrm{SO}_{4}$. This chemical separation precedes the LSC method, which is commonly used for radium determination in water samples. In order to improve the DL and the accuracy of the LSC method, the study of barium chloride was carried out. Based on the results obtained from the study, some conclusions were drawn, which are as follow: 1. The reagent of $\mathrm{BaCl}_{2} \cdot \mathrm{H}_{2} \mathrm{O}$ is contaminated with ${ }^{226} \mathrm{Ra}$, and the amount of ${ }^{226} \mathrm{Ra}$ in the reagent is equal to $62 \pm 6 \mathrm{~Bq} / \mathrm{kg}$.

2. The optimum amount of solution of $0.10 \mathrm{M}$ $\mathrm{BaCl}_{2} \cdot \mathrm{H}_{2} \mathrm{O}$ is equal to $14 \mathrm{~mL}$.

3 . In the case of occurrence of only one radium isotope (either ${ }^{226} \mathrm{Ra}$ or ${ }^{228} \mathrm{Ra}$ ), the DL of LSC method using $14 \mathrm{~mL}$ solution of $0.10 \mathrm{M} \mathrm{BaCl} \cdot \mathrm{H}_{2} \mathrm{O}$ for chemical preparation amounts to $0.005 \mathrm{~Bq}$ for ${ }^{226} \mathrm{Ra}$ and $0.030 \mathrm{~Bq}$ for ${ }^{228} \mathrm{Ra}$.

Acknowledgment. The work was financed by statutory funds of AGH University of Science and Technology (grant no. 11.11.220.01).

\section{References}

1. Nguyen, D. C., Duliński, M., Jodłowski, P., Nowak, J., Różański, K., Śleziak, M., \& Wachniew, P. (2011). Natural radioactivity in groundwater - a review. Isot. Environ. Health Stud., 47(4), 415-437.

2. Pietrzak-Flis, Z., Rosiak, L., Suplinska, M., Chrzanowski, E., \& Dembinska, S. (2001). Daily intake of ${ }^{238} \mathrm{U},{ }^{232} \mathrm{Th},{ }^{230} \mathrm{Th},{ }^{228} \mathrm{Th}$ and ${ }^{226} \mathrm{Ra}$ in food and drinking water by inhabitants of the Wałbrzych region. J. Radioanal. Nucl. Chem., 273(1), 163-169.

3. Rosa, M. L., Taddei, M. T., Cheberle, L. V., Ferreira, M. T., Santos, S. C., Avegliano, R. P., Bergamini, G.,
\& Maihara, V. A. (2015). Determination of ${ }^{234} U,{ }^{235} U$, ${ }^{238} \mathrm{U},{ }^{232} \mathrm{Th},{ }^{230} \mathrm{Th},{ }^{228} \mathrm{Th},{ }^{226} \mathrm{Ra},{ }^{228} \mathrm{Ra}$ and ${ }^{210} \mathrm{~Pb}$ in food from Brazilian total diet. J. Radioanal. Nucl. Chem., 306(3), 695-700.

4. Smodis, B., Cerne, M., Jacimovic, R., \& Benedik, L. (2015). Transfer of uranium and radium to Chinese cabbage from soil containing elevated levels of natural radionuclides. J. Radioanal. Nucl. Chem., 306(3), 685-694.

5. Starościak, E., \& Rosiak, L. (2015). Determination of uranium levels in the urine of Warsaw residents (Poland). J. Radioanal. Nucl. Chem., 304(1), 75-79.

6. Struminska-Parulska, D. I., Szymańska, K., \& Skwarzec, B. (2015). Determination of ${ }^{210} \mathrm{Po}$ in hair of domestic animals from Poland and Norway. $J$. Radioanal. Nucl. Chem., 306(1), 71-78.

7. Bode, K. T., Bylyku, E., Xhixha, G., Daci, B., \& Fishka, K. (2015). Determination of activity concentration of ${ }^{210} \mathrm{Po}$ in mussels (Mytilus galloprovincialis) from Butrinti Lagoon, Albanian Ionian coast. J. Radioanal. Nucl. Chem., 304(3), 1353-1358.

8. Basyigit, B., \& Tekin-Ozan, S. (2013). Concentrations of some heavy metals in water, sediment and tissues of pikeperch (Sander Lucioperca) from Karatas lake related to physico-chemical parameters, fish size and seasons. Pol. J. Environ. Stud., 22(3), 633-644.

9. Poggi, C. M., de Farias, E. E., Silveira, P. B., Filho, C. A., de Franca, E. J., Gazineu, M. H., \& Hazin, C. A. (2015) ${ }^{226} \mathrm{Ra},{ }^{228} \mathrm{Ra}$ and ${ }^{40} \mathrm{~K}$ in scales from boilers of industrial installations. J. Radioanal. Nucl. Chem., 306(3), 667-672.

10. Milvy, P., \& Cothern, R. (1990). Scientific background for the development of regulations for radionuclides in drinking water. In R. Cothern, \& P. Rebers (Eds.), Radon, radium and uranium in drinking water (pp. 1-15). Chelsea: Lewis Publishers.

11. UNCEAR. (2000). Sources and effects of atomic ionizing radiation. New York: United Nations.

12. Jodlowski, P., \& Kalita, S. (2010). Gamma-Ray Spectrometry Laboratory for high-precision measurements of radionuclide concentrations in environmental samples. Nukleonika, 55(2), 143-148.

13. Benes, P. (1990). Radium in (continental) surface water. In The environmental behavior of radium (pp. 373-418). Vienna: IAEA.

14. Kozłowska, B., Walencik, A., Dorda, J., \& Przylibski, T. A. (2007). Uranium, radium and ${ }^{40} \mathrm{~K}$ isotopes in bottled mineral waters from Outer Carpathians, Poland. Radiat. Meas., 42(8), 1380-1386.

15. Vesterbacka, P., Turtianen, T., Heinavaara, S., \& Arvela, H. (2006). Activity concentrations of ${ }^{226} \mathrm{Ra}$ and ${ }^{228} \mathrm{Ra}$ in drilled well water in Finland. Radiat. Protect. Dosim., 121(4), 406-421.

16. Vandenhove, H., Verrezen, F., Landa, E. R., \& Atwood, E. A. (2010). Radium. Chichester, UK: Wiley.

17. Nguyen, D. C. (2010). Promieniotwórczość naturalna wybranych wód mineralnych Karpat polskich. Kraków: JAK.

18. Szabo, Z., DePaul, V. T., Fischer, J. M., Kraemer, T. F., \& Jacobsen, E. (2012). Occurrence and geochemistry of radium in water from principal drinking-water aquifer systems of the United States. Appl. Geochem., 27, 729-752.

19. World Health Organization. (2008). Drinking water directions, radiological aspects. Geneva: WHO.

20. Council of the European Union. (2013). Council Directive 2013/51/EURATOM of 22 October 2013 laying down requirements for the protection of the health of the general public with regard to radioactive 
substances in water intended for human consumption. Brussels: O. J. EU.

21. Radenković, M. B., Joksić, J. D., \& Kovacević, J. (2015). Natural radionuclides content and radioactive series disequilibrium in drinking waters from Balkans region. J. Radioanal. Nucl. Chem., 306, 295-299.
22. Saito, T., Ohta, T., Koike, Y., \& Sato, J. (2002). A new analytical approach for ${ }^{226} \mathrm{Ra}$ and ${ }^{228} \mathrm{Ra}$ in environmental waters. J. Radioanal. Nucl. Chem., 255, 535-538.

23. Currie, L. A. (2008). Detection and qualification capabilities in nuclear analytical measurements. In P. Poviniec (Ed.), Analysis of environmental radionuclides. Amsterdam, Boston: Elsevier. 